\title{
Wat beteken 'kanon' vandag?
}

P M Venter

Departement Ou-Testamentiese Wetenskap (Afd A)

Universiteit van Pretoria

\begin{abstract}
What does 'canon' mean at present?

The notion of canon has become quite complicated. 'In textual criticism it is no longer possible to identify the canon with only one form of the textual tradition. Canonical texts originate and function in communities of faith. Childs' canonical approach does not accommodate this aspect properly. Sanders' canon criticism invites social scientific criticism like Gottwald's to enable one to understand the canon within a much larger framework. Even traditional studies of the history of the canon have to pay attention to a series of socio-cultural factors. In postmodern society the canon of the Bible works on a multidimensional level, confronting people with the living God who empowers them to live in God's presence.
\end{abstract}

Certainly, the way we should understand canon will be affected by what we understand the function of these canonical texts to be as signifiers of particular meanings to the canonizing community.

(Gottwald 1985:316)

\section{INLEIDING}

\subsection{Kanon en gesag as terme vir die Bybel}

Die kerk worstel al vir eeue met die basiese vraag: wat is die Bybel? Die Nederlandse Geloofsbelydenis van 1561 beskryf die Bybel as die 'heilige en Goddelike woord,' die 'geskrewe Woord van God,' waarin God die profete en apostels beveel het 'om sy geopenbaarde Woord op skrif te stel“ (Diensboek 1987:133). Nadat al die kanonieke boeke in Artikel 4 gelys is, handel Artikel 5 van die NGB oor 'Die gesag van die Heilige Skrif. Kanon en gesag word met mekaar in verband gebring as attribute van die Bybel: 'Ons aanvaar al hierdie boeke, en hulle alleen, as heilig en kanoniek om ons geloof daarna te rig, daarop te grond en daarmee te bevestig' (Diensboek 1987:134). 
Kanon is hier ' $n$ eksklusiewe en afgebakende versameling geskrifte wat in daardie vorm die gesag dra om woord van God te wees.

Op grond van die reformatoriese beginsel dat die kerk in 'n voortdurende proses van hervorming staan, moet die vraag noodwendig gevra word of die kerk na vier honderd jaar die Bybel presies nog in dieselfde terme sien. Watter inhoude word in ' $n$ toenemend postmoderne gemeenskap aan die begrippe gesag en kanon gegee? Watter rol speel navorsing in die betekenisgewing van hierdie begrippe? Wat beteken die begrip kanon vir ons vandag? Die doel van hierdie ondersoek is om die gebruik van die begrippe gesag en kanon op die gebied van die navorsing na die Ou Testament na te gaan en die inhoude wat tans daaraan gegee word, as nuanserings van die gebruik daarvan in die Nedelandse Geloofsbelydenis, aan te bied.

\subsection{Die term gesag}

In die huidige debat oor die gesag van die Bybel het lesers-georiënteerde benaderings die definisie van gesag voor nuwe uitdagings gestel. Binne die ekumeniese debat het daar groter bewuswording van die rol van tradisie en van die rol van die geloofsgemeenskap in die vorming en gebruik van die Bybel na vore gekom. Daarmee saam is die saak van die kulturele kontekstualiteit van alle uitsprake baie skerp omlyn deur die debat in feministiese kritiek.

Volgens Phyllis Bird (1994) is dit juis die feministiese kritiek op 'n Bybel wat in andro-sentriese terme geformuleer is, wat tot die kem van die vraagstuk deurdring. Hierdie kritiek aksentueer dat die Bybel 'n menslike produk is en daarom kultureel bepaal en begrens is. Dit is egter in hierdie volledig menslike woord met die volle kulturele gekontekstualiseerdheid daarvan dat die woord van God na mense kom. Die gesag daarvan lê nie in die woorde self nie, maar '.. in the ability of its words to confront readers with the story and the presence of a God who redeems sinners by assuming their weakness, and empowers the weak and the silent ... with visions and with speech' (Bird 1994:62). Die gesag van die Bybel lê '.. in the truth of its witness to a creating and redeeming power, which can and must be known as a present reality' (Bird 1994: 63).

Hierdie gesag moet telkens weer bevestig word in 'n dinamiese proses waar die Bybel binne die konteks van 'n kontinuerende geloofsgemeenskap gelees word. Die rede daarvoor dat die Bybel steeds gesag behou vir opeenvolgende generasies onder steeds nuwe omstandighede '.... is that it points beyond itself to God, whose purpose and nature are never fully or finally expressed in historical communications' (Bird 1994:63). Binne hierdie dinamiese relasie met God funksioneer hierdie Bybel met sy menslike kontekstualiteit as gesaghebbende woord van God. 'n Mens kan daarvan praat as kontekstuele funksionaliteit. 


\subsection{Kanonisiteit en funksionaliteit}

Wanneer die Bybel in terme van kanonisiteit omskryf word, het dit net soos die omskrywing daarvan in terme van sy gesag, met sy funksie binne die kulturele konteks te doen. Gottwald het hier bo opgemerk dat die inhoudsvulling van die term kanon afhang van die gemeenskap wat dit as kanon gebruik en die funksie wat hulle daaraan toeken. Resepsie-georiënteerde benaderings het, net soos in die geval van die begrip gesag, ook die gebruik van die begrip kanon voor nuwe uitdagings gestel. Kanon kan nie meer langer net in terme van literêre eksklusiwiteit en finaliteit verstaan word nie. Net soos die term gesag, moet dit binne 'n dinamiese proses verstaan en hanteer word. Ook hier is funksionaliteit die sleutelwoord.

Verskillende dissiplines in die teologiese wetenskap maak van die term kanon gebruik. Ons kyk vervolgens wat die meer bekende navorsers na die Ou Testament daarmee maak. Voorlopig kan ons opmerk dat dit vanuit 'n funksionele hoek lyk of hier van 'n 'verskuiwende kanonbegrip' gepraat kan word.

\section{DIE TEKSKRITIESE PROBLEEM MET DIE BEGRIP 'KANON'}

\subsection{Kanon en tekskritiek}

Tekskritiese navorsing maak ook gebruik van die begrip kanon. Die idee van 'n gesaghebbende teks of versameling van tekste speel hier 'n bepaalde rol. Die teks het 'n lang proses deurloop vanaf sy ontstaan tot die fase waarin dit gefinaliseer is en daarna herhaaldelik gekopieer is. Tekskritici moet besluit met watter teks hulle moet werk. Daar is minstens drie moontlikhede: die oorspronklike teks wat die Ou-Testamentiese outeurs self geskryf het, of die kanonvorm van die Ou-Testamentiese teks, of die oudste teks wat moontlik terug gevind kan word (vgl Deist 1988:198-9). Die Hebrew Old Testament Text Project van die United Bible Societies het vanaf 1969 oorspronklike tekste versamel en bestudeer. Hulle het hulleself telkens afgevra tot op watter stadium die navorsing moes teruggaan in die ontwikkeling van die Hebreeuse teks. Hulle het besluit op '.. the time frame when biblical texts began to function canonically or authoritatively, as norma normans, in ancient believing communities ...' (Sanders 1995:59). Daardeur het die begrip kanon ' $n$ wesenlike rol in tekskritiek begin speel.

Wanneer tekskritiek die begrip kanon gebruik, kan verwag word dat die begrip met eiesoortige inhoude gevul sal word. Tekskritiese navorsing dien tegelyk as korrektief op die inhoude wat elders aan die begrip kanon gegee word. Dit word uit die geskiedenis van die teks duidelik wanneer, waar, hoe en vir wie die teks as kanon gedien het. Sanders (1995:59) praat van hierdie wedersydse uitwerking as 'n '... interface between text criticism and canonical criticism ...' 
Die verbinding tussen kanon en teks loop alreeds 'n lang pad. Goshen-Gottstein het daarop gewys dat die pogings in Reformatoriese kringe om 'n gesaghebbende Hebreeuse teks vas te stel, 'n toepassing is van die sola scriptura-beginsel. Die oorspronklike teks moet herwin word omdat dit die werklike gesaghebbende openbaring bevat. Deist het egter uitgewys dat die eksklusiewe verbinding van kanon aan een bepaalde gefikserde teks ' $n$ verskuiwing in perspektief is, wat deur die sienings or inspirasie en foutloosheid in die ortodoksisme teweeg gebring is (vgl Deist 1992:37-38). Die sola scriptura van die Hervorming het gekombineer met die ad fontes van die Renaissance. Hierdie kombinasie het nie net die definisie van tekskritiek beïnvloed nie, maar ook die Skrifbeskouing in die teologie. Dit het aan die konsep kanon '... a "textual" definition' (Deist 1988:199) gegee. Wat Deist dus bedoel is 'n verskuiwing in kanondefinisie. Om die Hebreese Bybel te druk moes daar noodwendig vir 'n bepaalde lesing van die teks gekies word. Dit het die algemeen gebruikte of gestandaardiseerde teks (textus receptus) geword. Dit het egter veel verder as hierdie praktiese saak gegaan. Daar het ook 'n teksmatige invulling van die begrip kanon ontstaan. Die gesaghebbende inhoud is aan 'n gesaghebbende teks verbind. Die 'korrekte' lesing van die teks moes eers vasgestel word alvorens daardie teks deur eksegese teologies ontgin kon word om die gesaghebbende inhoud weer te gee. 'n Bepaalde Skrifbeskouing waarin die ontologiese status van Skrif dus 'n oorheersende rol speel, het hier die inhoud en omvang van die begrip kanon bepaal. Dit het op sy beurt die aard en rede vir tekskritiese navorsing en rekonstruksie van die teks bepaal.

Wanneer hy die nuwer navorsing na die teks in berekening bring, die geskiedenis van die Massoretiese teks van die Ou Testament nagaan en die gevolge van die ontdekking van die Qumranrolle in berekening bring, meen Deist dat daar 'n verandering in die definisie van kanon sal moet kom. Hy meen selfs dat die beginsel van die Hervormers van die Skrif-alleen in die slag kan bly: '... the reality of textual variety ... may question and perhaps even change their interpretation of the sola scriptura principle, and consequently also their view of Scripture on fundamental level' (Deist 1992:45).

\subsection{Meer as een vorm van die kanonteks}

Navorsing in tekskritiek het verskillende insigte ontwikkel wat van direkte belang is vir die gebruik van die konsep van kanon. Die eerste insig is dat dit nie uit die geskiedenis moontlik is om een bepaalde vorm van die teks uit te lig as dié kanon of as die oorspronklike kanon nie. Daar moet met 'n pluriformiteit van tekste rekening gehou word. Kanonvorms van die Ou Testament is nie net wat omvang betref so ryklik geskakeerd 
soos die Rooms-Katolieke versameling, die Grieks-Ortodnkse weergawe, die Koptiese en Protestantse weergawes nie, maar inhoudelik ook so gevarieerd as die Massoretiese teks, die Samaritaanse Pentateug en verskillende vertalings soos die Septuagint, die Targumim, Pehitta, Aquila, Theodotus en Summmagus.

Alle moderne gedrukte uitgawes'van die Hebreeuse Bybel, soos die Biblia Hebraica van Kittel, die Biblia Hebraica Stuttgartensia en die HUB (Hebrew University Bible Project), is elkeen die bewerking van 'n verskeidenheid Massoretiese tekste (in die meervoud). Daar bestaan nie so iets soos 'n gestandaardiseerde of oorspronklike Massoretiese teks in die enkelvoud nie. Dit is eerder 'n kollektiewe verwysing na oor die ses duisend beskikbare manuskripte van die Hebreeuse Bybel en dele daarvan, wat baie naby aan mekaar staan. Die term 'Massoretiese teks' is '... an abstract unit reflected in various sources which differ from each other in many details' (Tov 1992:22). Dit is '... a hermeneutical concept' (Deist 1988:85).

Hierdie fragmente van leer en papirusrolle in Hebreeus kom uit die Middeleeue en die tye daarvoor. Hulle lewer getuienis van 'n tradisie waarin die 'Bybelteks' deur verskillende instansies, op verskillende tye en op verskillende maniere hanteer is. Hierdie tradisie gaan terug na die tyd net na die vernietiging van die tweede tempel van Jerusalem in $70 \mathrm{n} \mathrm{C}$. Dit was 'n tyd van demografiese en sosio-religieuse veranderings waarin daar ' $n$ neiging was om tekstuele variasies van die tradisie te verminder (vgl Tov 1992:34). Dit is te betwyfel of daar in hierdie tyd een sentrale teks bestaan het wat as argetipe gedien het. Daar kan eerder gepraat word van proto-massoretiese tekste. Dit was 'n groep van konsonant tekste waaruit later die Massoretiese teks(te) sou voortvloei. Hierdie tekste het 'n baie ou tradisie weergegee wat in die geval' van sommige dele vir etlike honderde jare teruggegaan het. Alhoewel daar 'n sterk begeerte vir tekseenheid was, het dit nie weggevat dat daar verskille tussen die tekste was nie. Tog meen Tov (1992:34) dat die tekste van hierdie tyd '... a very small range of differences between them' vertoon.

Hierdie verskeidenheid manuskripte het as 'consonant base' of 'consonantal framework' (Tov 1992:23) gedien waarop die tradisie voortgebou het. Dit was eers net die sentrale stroom in Judaïsme wat hierdie manuskripte as Skrif aanvaar het (moontlik die Fariseërs - vgl Tov 1992:24, 28; Deist 1988:18, 67). Vanaf die 2e eeu het die meeste sektore van die Joodse gemeenskap dit ook begin aanvaar (vgl Tov 1992:23). Soos wat hierdie groep geskrifte die sentrale tradisie van die hoofstroom in die Judaïsme en later van die al die Jode geword het, is daar geen verdere veranderings daaraan aangebring nie. Geen toevoegings of weglatings is toegelaat nie. Op hierdie manier begin die neiging ontstaan '... to preserve the biblical text in the exact form in which it was current at a particular time in a particular circle ...' (Tov 1992:24). 
Tekste uit hierdie tradisie is talle kere gekopieer en as gevolg van die status daarvan is een van die verteenwoordigende tekste van die groep gebruik om die verskillende bekende vertalings te maak. Hierdie tekste is in Joodse geledere deur soferim gekopieer en deur naqdanim (vokaalkundiges) van vokale voorsien. Dit is tussen die sewende en elfde eeu gefinaliseer toe verskillende groepe massorim bepaalde aantekeninge daar by gevoeg het. Dit het bestaan uit vokalisasie, para tekstuele elemente, beklemtonings van gedeeltes en die Massoretiese apparatus. Dit was laasgenoemde aantekeninge wat aan hierdie tipe teks die benaming Massoretiese teks besorg het. Dit was veral die aktiwiteite van die Massoretiese groep van die Ben Asjer-familie in Tiberias aan die begin van die tiende eeu wat aan die materiaal finale beslag gegee het. Omdat die Ben Naftali-familie hulle ook met Massoretiese versorging en oorlewering van die tradisionele teks besig gehou het, is dit beter om soos Goshen-Gottstein eerder van die Ben Asjer verwerking as die Tiberynse Massoretiese teks te praat.

Die enigste gedeeite van die Hebreeuse Bybel wat in die dokumente van die Middeleeue redelik stabiel was, was die Wet en die vroeë profete. Dit was te wyte aan die feit dat ' $n$ vertellyn daarin gevolg word. Sedert die uitvinding van die boekdrukkuns is die Skrifprofete en die Geskrifte volgens die lys van Baba Bathra 14b in die Babiloniese Talmoed gerangskik en het daar ook in daardie deel stabiliteit gekom. Uit die duisende manuskripte wat op hierdie manier tot stand gekom het, is dit veral die dokumente wat hulle oorsprong uit die Tiberynse tradisie en sy kopieë het, waarvan in die moderne gedrukte uitgawes gebruik gemaak word.

Dit is uit hierdie kort oorsig duidelik dat daar op geen stadium 'n absoluut gestandaardiseerde weergawe van die teks (kanon) was wat in al die kopieë woordeliks identies was nie. Selfs al sou iemand wou beweer dat een van daardie weergawes nader is, of selfs identies is, met ' $n$ oorspronklike Bybelteks wat vroeër bestaan het '... we would still have to decide which Masoretic Text reflects this original "text" since the Masoretic Text is not a uniform textual unit, but is itself represented by many witnesses' (Tov 1992:11).

\subsection{Die geloofsgemeenskap}

Die tweede insig wat die tekskritiek ontwikkel het, is in die rol wat tyd en omstandighede in die proses gespeel het. Ons het alreeds Tov hierbo aangehaal wat na die konsonant basis van die tradisie verwys as die vorm van die teks wat in omloop was op 'n bepaalde tyd onder 'n bepaalde groep (vgl Tov 1992:24). Die teks wat uiteindelik oorgelewer is, was nie die enigste weergawe van die tradisie nie. Sosio-historiese faktore, soos onder andere groepsdinamika, het 'n deurslaggewende rol gespeel in die bepaalde vorm van die tradisie wat algemeen aaanvaar is. 
Dit was veral die 800 fragmente van leerrolle en die paar papiri wat sedert 1947 in die 11 grotte van Qumran gevind is, wat tot hierdie insig bygedra het. Hierdie dokumente dateer uit ongeveer 250 v C tot $135 \mathrm{n} \mathrm{C}$. Dit sluit sowat 190 Bybeltekste in en ander komposisies waarin die Bybelteks aangehaal is. Verskynsels soos die Psalmboek van Qumran wat agt meer psalms bevat as die latere Massoretiese teks en 'n ander rangskikking het, wys dat die tradisie meer as een vorm gehad het tydens die tydperk van die tweede tempel. Dit bring iemand soos Sanders tot die gevolgtrekking dat daar in hierdie tydperk net soveel kanons in omloop was as wat daar gemeenskappe was. Daar was ' $n$ verskeidenheid van tekste wat elkeen normatief was vir die bepaalde geloofsgemeenskap wat dit gebruik het. Daar was 'n vloeibaarheid tussen die verskillende gemeenskappe in die beskouing van watter literatuur ingesluit en uitgesluit en as gesaghebbend beskou kan word.

Die teksweergawe wat deur die sentrale stroom in Judaisme verkies is en op die Massoretiese tipe tekste uitgeloop het, was nie die enigste of noodwendig die beste teks van die Hebreeuse Bybel nie. 'Both the Hebrew parent text of [the Septuagint] ... and certain of the Qumran texts ... reflect excellent texts, often better than that of [the Masoretic Text]' (Tov 1992:24). Die ander versamelings het as gevolg van verskillende sosio-historiese omstandighede verlore gegaan. Die gemeenskappe wat ander teks tradisies nagevolg het, het of ophou bestaan (soos die mense van Qumran), of hulle gedisassosieer van Judaïsme (Samaritane en die Christene) en met eie en afsonderlike tradisies gewerk.

Dit is duidelik dat kanon hier op 'n ander vlak gewerk het as bloot net die tekstuele stratum wat in post-reformasie denke so oorheers het. Kanon het nie in hierdie gemeenskappe in terme van 'n gesaghebbende lys van boeke of as norma normata gewerk nie. In die lig van hierdie inligting kan die konsep van kanon '... no longer be a theoretical concept that somehow floated above the histories of actual believing communities for modern scholars to debate; it would have to be grounded in those histories' (Sanders 1995:58). Dit was '... socio-religious rather than qualitative factors ...' wat bepalend was vir die gebruik van ' $n$ bepaalde vorm van die tradisie (vgl Tov 1992:25). Dit wil ook vir Sanders voorkom of daar eerder in terme van funksionele kanonisiteit gepraat moet word (vgl Sanders 1995:58).

Die geweldige hoeveelheid tekste en die wye teksvariasies wat in hierdie tyd by Qumran en elders hanteer is, die oorweldigende 'textual multiplicity' (Tov 1992:163) van die tyd en die proses waarin afsonderlike boeke as tekstuele eenhede (as '... a single copy or tradition ...' - Tov 1992:172) tot stand gekom het, moet alles direk gesien word in terme van die funksionele gesag wat dit vir die geloofsgemeenskappe 
gehad het. Die teks waarna tekskritiek soek is '... that literary composition which has been accepted as binding (authoritative) by Jewish tradition ...' (Tov 1992:177). Teksversamelings was die produkte van verskillende interpreterende geloofsgemeenskappe wat birne 'n bepaalde stel van omstandighede daardie tradisies op 'n bepaalde wyse verkonkretiseer het en as hulle gesaghebbende vertolking van die gemeenskaplike tradisie gebruik het.

Hierdie kanoniese funksionaliteit vir die geloofsgemeenskappe van destyds speel direk in op die huidige geloofsgemeenskap se kanoniese hantering van die geskrifte wat uit die historiese proses ontvang is. Emmanuel Tov, is gedeeltelik partikularisties en gedeeltelik histories korrek wanneer hy sê: "The Bible contains the Holy Writings of the Jewish people, and the decisions that were made within this religious community to a great extent also determine the approach of the scholarly world towards the text' (Tov 1992:179; my beklemtoning). Deist benader die saak vanuit 'n Christelike hoek wanneer hy daarop wys dat die bestempeling van die Hebreeuse versameling as 'Ou Testament' 'n teologiese konsep was wat '... a variety of texts as referent, not a single, canonised, text' (Deist 1988:199) gehad het en gewerk het met '... a variety of texts witnessing to a variety of interpretative traditions, which should all be taken into account if we want to work "canonically"'(Deist 1988:199).

Die proses waarin oorlewering te midde van tekstuele veelvuldigheid deur 'n verskeidenheid van geloofsgemeenskappe op eiesoortige wyse as gesaghebbend hanteer is, moet as 'n lewende tradisie verstaan word. 'The various communities of faith shared a common tradition, which they concretised differently as a result of their differing social conditions. The variety of texts thus resulted from interpretation of tradition in differing conditions' (Deist 1992:42).

Tekste het nie as gefikseerde kanons gedien om 'n tradisie te legitimeer nie, maar was eerder die resultate van 'n lewende -geloofstradisie wat deur 'n verskeidenheid van teksvariante verteenwoordig is. In die Christelike gemeenskappe is daar nie monisties met slegs een weergawe van die tradisie gewerk nie. 'Scripture served as "fossilised examples of tradition" reflecting the state of the faith at a particular juncture or in a particular community' (Deist 1992:41). Omdat dit ' $n$ lewende tradisie is, is daar ' $n$ beweeglikheid wat deur die omstandighede en deur die sienings van die geloofsgemeenskappe bepaal word. 'What can become canonical is a tradition of knowledge, although such a tradition can change and does change as the needs of the community accepting that canon change' (Deist 1988:201). 


\section{CHILDS SE KONSEP VAN DIE KANON}

\subsection{Kanon en Bybelse Teologie}

Brevard S Childs het die begrip kanon baie prominent na vore laat kom ilı die teologie en die Bybelwetenskappe. Sy mikpunt is die teologie van die Bybel. Histories-kritiese navorsing is nie voldoende om by daardie Bybelse teologie uit te kom nie. Soos vir Von Rad die kerugmatiese maksimum in die eindresultaat van 'n tradisie-historiese proses lề (die Heksateug), lê die teologie van die Bybel vir Childs in die eindresultaat van 'n redaksionele-kompulatiewe proses (die Bybelboeke en die finale Bybel). Hierdie proses word vir albei binne die belydende geloofsgemeenskap voltrek. Dit is eers in die finale vormgewing van die boeke van die Bybel en in die newestelling van hierdie boeke langs mekaar as een Bybel, waarin die werklike teologie van die Bybel vasgelê is. Anders gesê: teologie moet op die vlak van die finale vorm gesoek word. Hierdie shape van die finale vorm is die sleutel tot daardie teologie van die Bybel.

Die begrip kanon dui tegelyk die finaliteit, die omvang en die gesag van hierdie shape aan. Die hantering van die finale vorm as kanon is die aangewese weg om te volg om by daardie teologie uit te kom. Omdat hierdie kanon 'n samestelling van stukke literatuur is, moet dit vanselfsprekend op die viak hanteer word van taaluitings wat in hulle onderlinge samehang bepaalde inhoude beteken. In die lig van die insig van die teksritiek hier bo dat dit nie werklik moontlik is om een bepaalde vorm van die teks uit te lig as dié kanon of as die oorspronklike kanon nie, moet gevra word wat Childs met kanon bedoel.

\subsection{Die Christelike kanon}

Kanon is vir Childs in die heel eerste plek die gesaghebbende versameling geskrifte van die Christelike kerk. Dit is 'n unieke kanon wat uit die Ou sowel as die Nuwe Testament bestaan. Wanneer die twee saam hanteer word, kom die unieke van die Christelike teologie na vore. 'What lies at the very heart of Child's proposals as its most controversial thesis is his insistence on the interdependence of reflection on the Old and the New as that which constitutes biblical theology' (Seitz 1994:90).

Childs se aandrang op die kanoniese konteks as die makrokonteks waarin Bybelnavorsing beoefen moet word, is beslis sy belangrikste bydrae tot die huidige navorsing. As kanon vir hom beteken dat alle Bybelnavorsing ook moet deurwerk tot op die vlak van die geheel van die kanoniese versameling en in gedagte moet hou watter betekenis daardie geskrifte in hulle totaliteit vir die Christendom het, sê Childs iets ontsettend belangrik. Binne 'n tyd van oorgang waarin basiese vrae nuwe vorms aanneem en nuwe 
antwoorde daarop voorsien word deur ' $n$ nuwe generasie van studente en navorsers, het Childs die vraag opnuit gestel oor hoe ons ons skriftelike erflating hanteer. Dis maklik om met Seitz (1994:93) saam te stem 'To remind the church to pay attention to the shape of its Christian scriptures, Old and New, New and Old, would seem like a remedial note to sound.'

Dit is egter wanneer dit by die fyner detail kom dat hierdie uitspraak problematies raak. Wanneer hy van die Christelike kanon praat, sal Childs die diversiteit van Christelike kanonversamelings in gedagte moet hou. Praat hy van die Rooms-Katolieke versameling, van die Etiopiese, van die Grieks-Ortodokse, of van die Prostestantse versameling? As hy vir die Massoretiese teks van die Ou Testament kies, gee hy ook nie enige motivering daarvoor nie (vgl Claassen 1996:223). Dit kan minstens verwag word dat hy sy keuse vir een bepaalde teksritiese uitgawe van die Massoretiese 'teks' sal verklaar en sal motiveer. Hoe verdiskonteer hy die Protestantse Ou Testament wat nie net in omvang verskil van die Massoretiese teks nie, maar selfs in die rangskiking van die materiaal wat dit daarmee gemeenskaplik het? As die Bybelse teologie regstreeks saamhang met die shape van die Christelike kanon moet verskille in omvang en in rangskikking tog beslis verskillende patrone vertoon wat verskil in teologiese beskrywing kan maak. As die uniekheid van die Christelike geloof saamhang met die unieke vorm van die kanon, moet daardie unieke tog omskryf word.

\subsection{Die finale vorm}

Childs gebruik verder die begrip kanon om die finale teks van alle vorige vorms te onderskei. Hy wil nie histories-krities met 'n rekonstruksie van die wording van die teks werk nie, maar die teks in sy finale gestalte hanteer. Die fases van daardie proses is nie meer rekonstrueerbaar nie, maar is vir hom ook nie ter sake nie. Dit gaan vir hom eerder oor wat die teks geword het as oor hoe dit so gekom het (vgl Kruger 1994:189).

Dit gaan ook nie vir Childs om die wedervaring van elke afsonderlike generasie nie, maar om die kollektiewe ervaring van al die geslagte wat geworstel het om tot begrip van God te kom. Hierdie kollektiewe ervaring is in die finale vorm van die teks geformuleer. Die kanonieke teks is ook losgemaak van die oorspronklike historiese raamwerk. Dit transendeer die oorspronklike hoorders. Die kanon se 'teologie' transendeer ook enige filologiese, literêre of historiese aangeleenthede rondom die teks. Die eindvorm het ' $n$ universele waarde wat tydloos relevant is vir elke gemeenskap.

Die finale vorm van die teks kan ook nie deurbreek word na vroeëre vorms daarvan nie, '.. to do this would be to ignore the very process by which ancient testimony became scripture in the first place' (Seitz 1994:92). Vir Childs is die eindvorm eers werklik Skrif. Die finale vorm het 'n teologiese status wat die vorms wat dit vooraf- 
gegaan het, nooit gehad het nie. By die afhandeling en die fiksering van die teks vind daar 'n oorgang plaas na kanonisiteit. Voor hierdie oorgang was kanonisiteit afwesig.

Dit is in daardie finale vorm wat die teks in kerk en sinagoge gesagvol funksioneer het. Daardie finale kanonvorm is ' $n$ universele tydlose openbaring wat voortdurend aktualiteit behou (vgl Brett 1991:76-115). Childs weier daarom ook om ekklesiologie of die houding van die leser/gemeenskap bepalend te laat wees in die ondersoek. Daar is vir hom twee beginsels wat aan die werk is by die lees van die Skrif sedert die vroee kerk. Die een is die vaste element van die behoud van die waarheid en die ander is die dinamiese gebruik van die Christelike gemeenskappe van hierdie getuienis. Die onderskeid word vasgevang in sy uitspraak 'we are not prophets or apostles', verwysend na die verskil tussen die vaste kern en die latere aanwending daarvan in die gemeenskap. Hy begin altyd met die eerste en beweeg dan eers na die tweede. Daardie statiese element is die punt waarom dit gaan en waarop die kanongroei van die begin af afgestem was.

Vanuit die tweede insig van die tekskritiek hierbo, naamlik dat tyd en omstandighede ' $n$ rol speel in die proses van kanonisering en dat elke teks die vorm van die teks is wat in omloop was op ' $n$ bepaalde tyd onder 'n bepaalde groep, het ons hier ' $n$ radikale verskil oor wat kanon beteken. Kanon is nie vir Childs iets wat los van menslike historisiteit staan nie, maar wat bo die tydelike uitstyg. Die bepaalde kanonvorm wat tot stand gekom het, is gesagvol omdat daardie vorm en geen ander (vorige) vorm nie as kanon aanvaar is en gebruik word. Daardie kanonvorm staan in ' $n$ een-tot-een verhouding met die teologie wat dit aanbied. Soos daardie eindvorm gefinaliseer en gefikseer is, so is die openbaring wat dit bied 'n konseptuele wêreld van goddelike waarheid wat universeel en tydloos en daarom altyd aktueel en toepaslik is.

Dit is hierdie vulling van die konsep kanon wat in bepaalde teologiese kringe op 'n manier verstaan is wat aan Childs 'n bepaalde populariteit oor die laaste dekades verleen het. Iets hiervan kom na vore in die waardering dat Childs in sy kanonbenadering '... die onskeibare verhouding tussen die kanon as lys van boeke en die kanon as norm' (Claassen 1996:219) handhaaf. In sy doktorale proefskrif oor Childs merk Claassen (1996:220) onder andere op: 'Die feit dat die kanon as gesaghebbend deur die geloofsgemeenskappe ervaar is, onderstreep die beginsel dat die Skrif sy eie gesagsdraer is. Van die begin af het die teks gesag gehad, die geloofsgemeenskappe het dit so aanvaar en as kanon erken. Daar is dus 'n organiese groei van gesag uit die teks self.'

Die kanon dra volgens hierdie beskouing 'n inherente gesag wat kan funksioneer sonder enige bepaalde geloofsgemeenskap en selfs sonder God. Die teks het 'n ontologiese status (vgl Deist 1988:199) waarvolgens dit selfstandig kan funksioneer. 'n 
Kanon is vir Childs 'n versameling van tekste wat op die vlak van taaluitings funksioneer wat in hulle onderlinge samehang bepaalde inhoude beteken. Childs fokus op wat die New Critics noem die estetiese dimensie van die teks. Dit is die shape van die kanon, die Bybel as finale produk wat hier op sy eie funksioneer (vgl Spina, in Sanders 1995:60). Die klem verskuif van die Bybelse kritiek met sy tradisionele historiese belang na 'n meer literêre benadering (vgl Claassen 1996:200-201).

Claassen wys dan ook tereg uit dat Childs min aandag gee aan die prosesse en die gemeenskappe wat betrokke is (Claassen 1996:221), die dinamiese proses wat die teks voorafgaan (Claassen 1996:222) en aan die groepe en individue deur wie en vir wie die finale vorm tot stand gebring is (Claassen 1996:222). Childs veronderstel ook te maklik dat '... die tradisie deur godsdienstige motiewe gevorm is. Daar is talle gevalle waar ander faktore ' $n$ rol gespeel het byvoorbeeld politieke en sosiale faktore wat ' $n$ invloed uitgeoefen het op die finale vorm van die teks' (Claassen 1996:222).

\subsection{Die debat rondom Childs}

Wat Childs met kanon bedoel, staan reëlreg teenoor die siening oor kanon wat in tekskritiese kringe voorkom. Die kontrovers moet teen 'n breër teologiese agtergrond gesien word. Scalise stel die posisionerings van Barth en Childs aan dieselfde kant teenoor dié van Sanders en Bultmann aan die ander kant. 'The Barth-Bultmann debate is in large measure continued and extended in the debate between Childs and Sanders over the canonical interpretation of the Bible' (Scalise 1994:82).

Childs en Sanders verteenwoordig 'theologically divergent proposals' (Scalise 1994:82). By Childs en Barth is daar albei 'n poging om die teks self te laat praat, post-kritiese teologie te beoefen, binne 'n konfessionele konteks met die spanning tussen die historiese en teologiese aspekte van die Bybel te worstel, 'n keuse uit te oefen vir die kanon as die vertrekpunt vir eksegese en boonop die Bybel te beskou as transparante getuienis van die openbaring van God (vg Scalise 1994:61-79). Die kanonbenadering van Childs is ' $\ldots$ in large measure an extension of Barth's theological hermeneutics' (Scalise 1994:79-80).

Die teologiese hermeneutiek van Childs staan teenoor die eksistensialistiese hermeneutiek van Sanders. Childs se kritiek op Sanders is dat hy analogies eksistensieel dink en ' $n$ direkte ooreenkoms sien tussen die profete en apostels en die gelowiges van vandag. Dit staan lynreg teenoor Childs se standpunt van 'we are not prophets or apostles'. Die funksie van die kanon lê volgens Childs juis daarin dat dit die universele openbaring aanbied wat die historiese transendeer. Dit is menslike getuienis wat van die openbaring getuig. Die rigting loop van God na mens, nie andersom nie. Die 
kanon is nie die uitkoms van historiese prosesse wat daaraan vorm help gee het nie. Dit is wat Sanders beweer waneer hy die kanon sien as die proses waarin Israel soek na 'n gemeenskapsidentiteit. Sanders se teologie wat God definieer as 'the Integrity of Reality' (Scalise 1994:84), is teologie '... [that] moves in classic liberal Protestant fashion from human experience to divine reality' (Scalise 1994:84). Uit hierdie hoek is dit dar ook die bevinding dat '... Sanders' analysis of the nature of canon turns on the question of human identity' (Scalise 1994:84).

Vanuit die hoek van Sanders is die probleem met die standpunt van Barth en Childs dat hulle die kanonieke pluralisme ignoreer ten gunste van die gedagte dat daar ' $n$ vaste Bybelse kern in die teks is. By Childs ly die diversiteit van die Skrif skade (vgl Claassen 1996:221). Childs spreek nie die probleem van 'n pluraliteit van teologieë in die een kanon aan nie (vgl Bossman 1993:22-23). Die kanonbenadering van Childs vereis die intertekstuele lees van tekste. Op die ou einde word hierdie projek gekelder omdat alles vanuit die Nuwe Testament gedoen word. Ou-Testamentiese gedeeltes kry meer relevansie as dit wel in die Nuwe Testament aangehaal word. Dit werk verengend in op die gebruik van die kanon (vgl Claassen 1996:220).

Aan die een kant staan Barth en Childs vir wie die kanon die deursigtige getuienis is van 'n universele openbaring daaragter. Die teks lei direk tot daardie openbaring. Die formulering van daardie openbaring skop egter terug wanneer dit nie reg aan al die dele van die kanon en aan die diversiteit van menslike kulturaliteit laat geskied nie. Aan die ander kant staan mense soos Sanders wat die kanon as produk van menslike historisiteit sien. Die beklemtoning van historisiteit loop weer die gevaar dat oorhistorisering plaasvind ten koste van die teologiese aspek ( $\mathrm{vgl}$ die verwysing na Childs en Von Rad, in Brett 1991:76-77). Dit is egter onwaar om soos Scalise te beweer: 'For Sanders the concept of canon is first of all historical and only later theological, in contrast to both Barth and Childs, for whom the canon is an explicitly theological notion' (Scalise 1994:84). Die teendeel kan met meer reg gestel word dat die gebruik van die konsep kanon by Childs so verabsoluteer is dat dit nie altyd duidelik is of hy lys, norm of kanon bedoel nie. Die ongenuanseerde hantering van die konsep kanon is paradoksaal vir die vader van hierdie konsep in hedendaagse teologie. Dit is juis een van die groot leemtes in sy benadering ( $\mathrm{vgl}$ Claassen 1996:221).

\subsection{Childs se navolger Rendtorf}

Childs se ongenuanseerdheid word in 'n mate by sy navolger Rendtorff, opgevang. Hy beperk in die eerste plek die kanoniese benadering tot die Ou Testament. Tweedens laat hy ruimte daarvoor oop dat die kanon in sy Massoretiese vorm of in sy Septuagint vorm gebruik kan word. Die belangrikste is egter dat 'n holistiese benadering gevolg 
moet word en die teks in sy 'finale vorm' hanteer moet word, selfs al bevat dit teenstrydighede en spannings. Die derde aspek wat Rendtorff verander, is dat hy die verskeidenheid in geloofsgemeenskappe in ag neem '... one of the presuppositions of a canonical interpretation is the conviction that the Bible became canonized and served as the holy scripture of a community of faith, first the Jewish community later also the Christian. This is one of the motivations for using the canonical approach: to understand the Bible in the form in that the Jewish and the Christian community understood it and lived with it through the centuries' (Rendtorff 1994:13).

\section{SANDERS SE KANONKRITIEK}

Om die waarde van Sanders se bydrae te bepaal, is dit nodig om te toets of Scalise se bewering waar is dat die konsep kanon by Sanders eers in tweede instansie teologies is. Sanders het in sy navorsing met die canonical process en die hermeneutics of biblical intertextuality (Sanders 1995:59) gewerk. Die subdissiplines wat hy hiervoor gebruik is, wat hy noem comparative midrash en die hermeneutical triangle. Hiermee bestudeer hy die manier waarop ouer gesaghebbende tradisies telkens aangehaal en aangepas is in antieke geloofsgemeenskappe. Die totale geskiedenis van voortdurende herbewerking noem hy die canonical process. Die studie in sy geheel noem hy canonical criticism.

Hierdie proses is vir Sanders van meet af aan (pace Scalise!) 'n teologiese onderneming. Deur sy hermeneutiese driehoek dui hy aan hoe die tradisie gewerk het tussen die drie punte van die gebruikte ouer tradisie, die sosio-politieke situasie en die receptor hermeneutics waarvolgens die ouer tradisie hanteer en toepaslik gemaak is. Die wesenlike kenmerke van hierdie hermeneutiek was theocentric and monotheizing. Wat hy daarmee bedoel is dat die '... receptor hermeneutic that drove the canonical process by which certain literature ended up in the canon and other literature did not, was in resonance with the first three of the Ten Commandments ...' (Sanders 1995:59). Aan die hand van die verbod op veelgodedom, afgode en ontheiliging van God se Naam, is ouer tradisie deur dinamiese analogie, of teregwysend of bemoedigend op nuwe situasies toegepas.

Hierdie proses het die eerste keer in die antieke geskiedenis begin en '... became a so-called "tradition", and thence got on a tenure track toward canon' (Sanders 1995: 59). Die proses is voortgesit '... each time thereafter that Scripture or tradition was reappropieted so effectively that it survived the canonical process and got on a tenure track toward a community's canon' (Sanders 1995:61). Hierdie proses het nie opgehou toe die kanon gestabiliseer het nie. 'In my view closure did not make that much difference in the ongoing canonical process. Once firm stabilization of text and canon set 
in, communities found the hermeneutics whereby they continue to render the stable fluid; they continued to need to know who they were and how to live in ever-changing circumstances' (Sanders 1995:62). Hierdie proses gaan nog steeds voort en sal bly aangaan tot op die laaste dag. Dit is dan ook die funksie van Skrif '... to provide the paradigm whereby the process is discerned and whereby it continues in believing communities till now' (Sanders 1995:62). Kanonkritiek gaan vandag steeds voort om die Westerse kultuurbeskouing van gesag uit te daag en met die werklikheid van God te konfronteer.

Sanders sien die verskil tussen homself en Childs in die locus van kanonieke gesag. Dit is vir Childs geheel en al beperk tot die finale worm van die teks. Die hermeneutiek van die teks word geheel van daaruit bepaal. Vir Sanders is die voortgaande kanonproses die locus van gesag. Die Skrif verskaf die paradigma waarvolgens daardie proses verloop. Dit gee nie net uit die verlede 'n aanduiding hoe die proses verloop het nie, maar instigeer ook die voortgang van die proses in die hede.

\section{DIE GESKIEDENIS VAN KANONVORMING}

\subsection{Die tradisionele benadering}

Die tweede been van Sanders se hermeneutiese driehoek betrek die sosio-historiese situasie by die kanoniseringsproses. Sowel hy as Childs het 'n saak daarvoor probeer uitmaak dat daar 'n samehang en verhouding is tussen die ontstaans- en redaksiegeskiedenis van 'n Bybelboek en die kanonieke status en die funksie van daardie boek binne die gèloofsgemeenskappe daarna (vgl Van der Kooij 1995:59).

Die ondersoek na die sosio-historiese konteks van die ontstaan en groei van die kanon het reeds lank voor hulle tyd baie aandag in die navorsing geniet. Veral sedert die ontdekking van die Qumranrolle het die navorsing na die geskiedenis van die kanonteks(te) opgevlam en in die lig van nuwe getuienis bepaalde aanpassings gemaak. Veral navorsers soos Sundberg, Leiman en Beckwith het op hierdie gebied die leiding geneem. Tradisioneel was die ondersoek na die geskiedenis op die fase van die afsluiting en fiksering van die kanon gefokus (vgl Deist 1988:85). Flavius Josefus en Filo was die hoofbronne van inligting en die tye van Esra en Jamnia is as die belangrikste beskou. Die motivering was natuurlik die gedagte dat ' $n$ kanon gesaghebbend funksioneer wanneer dit afgesluit en amptelik afgebaken is van ander literatuur. Die geskrifte van die Ou Testament begin eers normatief funksioneer wanneer dit deel is van 'n amptelike kanon. En hierdie prosesse is beskryf en betuig in die bepaalde literatuur en tyd waarop die fokus geval het. 
Hierdie ouer benadering kan byvoorbeeld gesien word in die opmerking van Dunbar (1995:314) wanneer hy sy oorsig oor die ontwikkeling van die Ou-Testamentiese kanon gee, dat hy dit in ooreenstemming met sy definisie van die kanon doen. Hy merk op: '... our concern is not merely with the status of a writing as inspired Scripture but also with its distinctiveness from other writings and its place as part of a recognised corpus.' Die definisie van kanon werk nog hier in terme van literatuur wat geinspireer is, wat afgebaken is en ingesluit is by 'n gesaghebbende korpus. Hierdie definisie het in die nuwer navorsing na die wording van die kanon bepaalde wysigings ondergaan. Die aard daarvan word duidelik in die corsigte van Van der Kooij (1995) en Collins (1995) oor die navorsing na die wording van die kanon. Die rol van Jamnia, die langdurigheid van die proses en die kompleksiteit van gemeenskappe en hulle literatuur kom duidelik na vore.

\subsection{Kanonbewussyn}

Bybelboeke het van vroeg af reeds ' $n$ kanonieke of vergelykbare status geniet, maar dit het nie noodwendig '... nauwkeurige, stabiele tekstoverlevering impliceert' (Van der Kooij 1995:60) nie. Die geweldige variasie in teksoorlewering wat hier bo by die tekskritiek reeds uitgewys is, die rol van die geloofsgemeenskap in die hantering van tekste en die langsame proses van eventuele uitkristallisering van een tipe teks, wys uit dat die begrip kanon nog nie teen die tyd van die afsluiting daarvan as aanduiding van ' $n$ amptelik vasgestelde lys van boeke gebruik is nie. Daar was wel 'n 'canon consciousness' (Collins 1995:230), wat so ver teruggaan as die promulgering van Josia se wetboek in 621 v C. Die gedagte van 'n omskrewe korpus begin eers in die voorwoord tot Ben Sira ontplooi in die laat tweede eeu v C. Daar was teen $70 \mathrm{n} \mathrm{C}$ 'n 'core canon' (Collins 1995:232) van Wet en Profete aanwesig waaroor daar konsensus was. Daarnaas was daar nog ' $n$ hele aantal ander boeke in omloop.

Collins se teorie is dat daar aan die einde van die eerste eeu onder leiding van die Farisese party by Jamnia ' $n$ '.. shrinking of the corpus of religious literature ...' (Collins 1995:238) plaasgevind het, wat uitgekristalliseer het in 'n gedemarkeerde kanon wat eventueel aanvaarding by ander groepe geniet het. Volgens Shaye Cohen (aangehaal by Collins 1995:238) is daar by Jamnia ' $n$ koalisie van verskillende groepe gevorm en is enigeen wat buite hierdie koalisie gestaan het as minim gebrandmerk. Hierdie konsensus standpunt van Jamnia, oorwegend Farisees, het die toon begin aangee. Hierdie standpunt het in Joodse geledere om verskillende redes dominant geword en al die ander standpunte corskadu en uitgewerk.

Redes vir die aanvaarding van hulle standpunt, soos die ouderdom van die boeke wat hulle gekies het, of die profetiese oorsprong daarvan, kon 'n rol gespeel het (vgl 
Leiman 1981:57-61). Jamnia kon ook 'n baie sterk polemiese inslag gehad het en probeer wal gooi het teen ketterse strominge en die Christendom (vgl Veltri 1990:215). 'To a great degree, decisions on canonicity may have been determined by pragmatic rather than ideological considerations' (Collins 1995:239). Onder praktiese maatreëls verstaan Collins (1995:240) dat deur '... restricting the number of "properly accredited" books the sages provided a common frame of reference for their debates and reduced the risk of sectarian division.' Dit het aan Judaisme oorlewingsmoontlikheid in 'n tyd van krisis gegee. Wat ook al die funksionele redes, die konsensus standpunt het daartoe gelei dat (soos reeds hier bo by tekskritiek aangedui is) die geskrifte van ander groepe in onbruik en vergetelheid geraak het.

Eers vanaf die vierde eeu $\mathrm{n} C$ het die begrip kanon die inhoud begin kry van 'n gesaghebbende lys van boeke. Dit is daarom onhoudbaar om die geskiedenis van die kanon teen sy afsluitingfase tussen die vyfde eeu $v$ C en eerste eeu $n$ nale lys van kanon boeke te beskryf. Daar moet vir hierdie tyd 'n onderskeid gemaak word tussen kanon enersyds in terme van heilige en gesaghebbende boeke en andersyds in die sin van 'n vasgestelde lys van boeke (vgl Van der Kooij 1995:62).

\section{DIE SOSIO-IDEOLOGIESE KONTEKS VAN DIE KANON}

\section{1 'n Multidimensionele benadering}

Die bestudering van die geskiedenis van kanonwording werk binne 'n breër raamwerk as net bloot historiese navorsing. Kanonwording, soos ook huidige kanongebruik, het binne ' $n$ sosiale matriks verloop. Kanons is na alles '... guides for social meanings and communication ...' (Bossman 1993:2) wat die sienings van mense reflekteer en beheer. Die (literêre) elemente van die normerende tradisie van Israel is onderwerp aan 'n voortgaande proses van kondensering, uitbreiding, teenoorstelling, ineenvlegting en prioretisering. Hierdie proses is 'n manier van '... underscoring the ideological component of Israelite society and religion' (vgl Gottwald 1985:313). Elke fase of vorm van die kanon reflekteer die sosio-religieuse belang van die groep of van groepe in die maatskappy in daardie bepaalde tyd. Dit versimboliseer die waardes en teologiese beskouings wat in daardie konteks gegeld het. Dit dien as 'n funksionele '... map of reality ...' (Bossman 1993:13) vir almal wat hulle in daardie maatskappy bevind of hulle met daardie geloofsgemeenskap identifiseer.

Die normerende tradisie was 'n proses met veranderlike komponente in sowel sy literatuursamestelling as die deelnemende maatskappy. Dit het meegebring dat die kanon in sy fases van vorming en later in sy gelaagde vorm van 'n voltooide kanonver- 
sameling, 'n opvolgende reeks betekenisveranderings vertoon. Die 'metaphorical range of reference' (Gottwald 1985:318) van die kanontradisie korrelleer telkens met die bepaalde sosio-ekonomiese, politieke en kulturele belange van die godsdiensgemeenskap en loop dus met die sosio-historiese veranderings saam. Dit beteken dat die vlak waarop die normerende tradisie as kanon funksioneer, multi-dimensioneel is. Wat ' $n$ kanon is en hoe dit werk lê op baie meer as net een vlak. Om dit te bestudeer is 'n komplekse onderneming wat multidissiplinêr hanteer moet word. Dit vereis '... sensitive and skillful use of tools from a variety of sciences, including linguistics, theology, comparative religion, comparative iaw, literary criticism, archeology, paleography, anthropology, and history' (Bossman 1993:15).

Gottwald (1985:316) wys verskillende sosio-historiese redes uit vir die vorming van 'n kanontradisie: om die voortgang van bepaalde gedragspatrone te verseker; interne eenheid of konsensus in die gemeenskap te versterk; identiteit aan die gemeenskap te gee; gehoorsaamheid aan die draers van die tradisie te verseker; om gekoesterde vertellings te bewaar. Hierdie doeleindes is weer met 'n wye spektrum van tegnieke bereik wat wissel van die manier waarop literatuur hanteer is tot maniere waarop die maatskappy manipuleer is. Hierdie motiverings en tegnieke word telkens in komplekse en bykans onoorsigtelike kombinasies verbind om binne die bepaalde problematiek en uitdagings van 'n bepaalde tyd die kanontradisie voort te sit. Enkele aspekte van die doel van kanonwording en die tegnieke wat daarvoor gebruik is en hulle komplekse verweefdheid $k a n$ in die volgende deel gesien word.

\subsection{Verskillende aspekte}

Vir Leiman (1981) lê die hermeneutiek waarvolgens besluit is oor wat in die kanon inof uitgesluit moes word, volledig op ideologiese vlak. Dit was nie teenstrydighede, of ouderdom of ongelykhede in die materiaal wat oorgeneem is, wat bepaal het wat ingesluit was al dan nie. Dit is gewoon bepaal deur die houding teenoor die kring waaruit 'n dokument kom. Vier oorwegings het gegeld: boeke wat na die beeindiging van profesie teen ongeveer 150 v C geskep is, is nie meer ingesluit nie; boeke wat in Grieks geskep was, is uitgesluit; boeke in Hebreeus wat selfs in die Bybelse tyd geskryf is, maar wat strydig was met die tradisionele halakiese onderrig, was uitgesluit; boeke waarvan die inhoud aanvaarbaar was, maar wat met sektariese groepe geassosieer was, is uitgesluit. Die geloofsgemeenskap waarin die halakiese uitleg van die tradisie plaasgevind het was die norm. Hulle het die mag gehad en vanuit hulle groepsidentiteit en aversie teen ander groepe die besluit geneem. 
Brakke toon aan dat die funksionering ván die kanon as geslote versameling op presies dieselfde vlak lê. Athanasius het in die vierde eeu $n \mathrm{C}$ vir die eerste keer die begrip kanon begin gebruik en ook daarmee 'n geslote lys van Bybelboeke bedoel. 'n Sosio-politieke analise wys dat dit sy strategie was om sy kerklike opposisic te beheer. Die agtergrond van die stryd was die kragmeting tussen die so genoemde akademiese en episkopaalse kringe in die Christendom. Athanasius se dispuut met ander Egiptiese Christene oor die Bybelse kanon het nie net oor 'n lys van kanonieke boeke gegaan nie, '... but reflected more fundamental conflicts between competing modes of Christian authority, spirituality, and social organization' (Brakke 1994:399). Dit het nie hier gegaan oor 'n kanon aan mense wat nie cen gehad het nie, of om 'n kanon te sluit wat tot dusver oop was nie, '.. but rather of a bishop promoting a certain type of biblical canon ...' (Brakke 1994:408). Athanasius het 'n bepaalde soort kanon propageer omdat dit vir hom 'n magsmiddel was in interpersoonlik konflikte. Dit het hier eerder. gegaan om '... a conflict among authoritative persons and the social institutions and practices that surrounded them, which included scripture' (Brakke 1994:417).

Van Aarde dui aan dat kanonvorming ook binne die spel om mag in die post-eksiliese Judaisme gesien moet word. In 'n tyd van 'n corbeweeg na 'n agrariese tipe gemeenskap in die Mediterreense wêreld, was daar amptenare uit die ondersteuningsgroep van die elite wat die guns van die bevolking probeer wen het en beheer probeer kry het oor die kwynende lewensbronne. Hulle wend die toenemende mag van skrif en geld aan om hierdie doel te bereik. Veral skrif in die vorm van 'n kanon was geskik as 'n '... ideological vehicle for domination and oppression' (Van Aarde 1994:578). Die Ou-Testamentiese kanon kan terug herlei word na hierdie post-eksiliese Judese amptenare wat die ongeletterde $90 \%$ van die bevolking beheer het deur die '... compilation of a 'canon' of sacred writings, implementation of schools to interpret these texts and the provision of education so that their ideology ... could constitute the frame of reference among the masses that concurred with the symbolic and social world of the elite' (Van Aarde 1994:580).

Veltri (1990:21) beskryf die gebeure by Jamnia aan die hand van 'n '... Überlieferungsdynamik der biblischen und rabbinischen Literatur.' Hierdie dinamiese proses het drie aspekte gehad wat al drie regstreeks met kanonisiteit te doen gehad het. Die cerste was die invloed wat bestaande literatuur op gemeenskappe het en die groei wat daardie literatuur ondergaan. Die tweede was die bewustheid van die geloofsgemeenskap van die ‘... religiös-politisch-soziale Wichtigkeit dieser Bücher' (Veltri 1990: 211). Die derde aspek was die bepaalde hermeneutiek (ideologie) wat in die gemeenskap aan die werk was waarvolgens hulle tekste verwerp of angewend het. Die manier waarop teks, gemeenskap en vettolking van die tekste op mekaar inwerk, was eie- 
soortig aan daardie situasie. Uit daardie eiesoortige dinamiek is die voortgang van die kanonproses gestimuleer.

Deist (1995) wys op die rol van veranderings en krisisse in kanonvorming. In sulke tye word uit die tradisie literêre kanuns geskep om anomie te keer en die identiteit van die groep te herstel of te behou. Die historiese bewussyn van enkelinge en groepe skep altyd gesagvolle literatuur met 'n '... identitätstiftende Funktion' (Jeismann 1985: 13), 'n 'Legitimierungsfunktion' (Jeisman 1985:14) en 'n 'Orientierungsfunktion' (Jeisman 1985:14) om hulle eiesoortigheid, reg op aansprake en plek binne die gang van die geskiedenis te kry. Die groepsidentiteit bepaal die literatuur wat ingespan word om 'n literêre kanon te vorm. Daardie kanon verskaf groepsgrense en dit ostraseer mense uit die groep.

In hierdie proses is dit gewoonlik groepleiers in gesagsposisies, soos Esra en Nehemia met hulle regsvoorskrifte, wat hierdie aksies namens of vir die gemeenskap onderneem. Die motiewe hierin is nie net religieus nie. Dit gaan dikwels oor die botsing in belange tussen groepe of individue, soos hierbo aangetoon. Vertellings en berigte word die wêreld ingestuur om as kontranarratiewe te dien '... teen die totaliserende en marginaliserende aard van meesternarratiewe, teen die aanspraak op universele waarheid, teen die dominering van 'n gemeenskap deur die elitistiese belangegroep wat baat by die meesternarratief omdat dit hulle magsbasis versterk' (Breytenbach 1997:1166)

Omdat die situasie telkens deurslaggewend is vir die vorming van die kanon, is darr elke keer 'n ander kombinasie van faktore. Soos Veltri angetoon het dat elke situasie eiesoortig is in die manier waarop teks, gemeenskap en vertolkers van dadrdie teks op mekaar inwerk (vgl Veltri 1990:211), toon Deist aan dat dit die spesifieke kanonkonteks is, die interaksie tussen die perspektief wat uit die teks spreek, die kanoniseeerders en die situasie wat die literêre kanon bepaal (vgl Deist 1995:78). Dit is die manier waarop ' $n$ teks met ander faktore saamwerk wat die funksie van kanon bepaal. In die tyd na die ballingskap het die groeps definisie van nasionalisties na etnoreligieus verskuif. Om hierdie skuif te kon hanteer is gebruik gemaak van verskillende rites, soos besnydenis, sabbat en kosjer-wette sowel as die stories en voorskrifte wat in die tradisie van die Moseswette vervat is om dit te versterk.

\section{3 'n Meer omvattende benadering}

Die wordingsgeskiedenis van die Ou Testament kan dus vanuit 'n ander gesigspunt as die tradisionele ondersoek word. Dit kan gebeur binne die raamwerk van die '... historiese bewussyn, die kontekstualiteit en intertekstualiteit van tekste, meesternarratiewe en kontravertellings, en belangegroepe agter kanonisering' (Breytenbach 1997:1168). 
Vanuit 'n ideologies-kritiese hoek lê die wesenlike van 'n kanon nie inherent in sy literatuur, die aard of vorm daarvan nie, '... but in the context in which it is interpreted and, therefore, in the special set of intertexts of which it forms part. These intertexts include power relations, views of anthority, specific beliefs and religious traditions, particular textual theories and methodologies with their implied interpretive strategies, readers' expectations, and so forth' (Deist 1995:78).

\section{DIE KANON IN DIE HEDENDAAGSE GEMEENSKAP}

'n Teks dwing 'n leser om vanuit sy eie sosio-politieke werklikheid betekenis aan die teks te gee. In terme van Foucault se siening vind daar 'n sosiale produksie van waarheid en daardeur uitoefening van mag plaas. Die ontmoeting met die teks het pragmaties-politieke en ekonomiese konsekwensie. Dit skakel met die institusionele strukture in die maatskappy wat die mag het om die waarheid te bepaal en te produseer. In die kritiese diskoers met die teks word altyd sosiale mag uitgeoefen. Dit impliseer dus radikale selfrefeleksie en nadenke oor die voorwaardes waarop 'n teks gelees moet word om geldigheid en gesag in die kontemporêre gemeenskap te besit (vgl Venter 1997:580-598).

Kanons werk op dieselfde manier. Literère kanons (vgl Ohlhoff 1993) word geskep wanneer mense in verskillende hoedanighede en om verskillende redes keuses uitoefen oor bestaande literatuur en deur insluiting (of uitsluiting) daarvan in nuwe versamelings bepaalde kanonieke funksionaliteit daaraan gee. In hierdie proses word bestaande kanonversamelings nie net gedepolitiseer en ewiggeldende waardes daaraan ontsê nie, maar gevestigde belange word beskerm en die waardesisteem van die samelewing beheer. Volgens Even-Zohar (vgl Ohlhoff 1993:64-65) se poli-sisteemteorie word daar in dinamiese kanonisiteit deur nuwe modelle voortdurend sisteme gegenereer waarvolgens seleksie uitgeoefen word en kanonisiteit bepaal word. Die dominante sosiale groep beheer hierdie sisteemwording en oefen mag uit ten nadeel van die subkulture wie se versamelings uitgeskakel word as illegitiem en in die vergetelheid verval.

Die gebruik van die Bybel as kanon is eweneens ook nie staties nie. Dit dwing die lesers daarvan om vanuit hulle sosio-politieke werklikheid hulle eie metafoor oor God te produseer. Hulle diskoers het pragmaties-politieke en ekonomiese konsekwensie omdat dit daarop aanspraak maak om geldigheid en gesag in die kontemporêre gemeenskap te besit. Die sisteem wat hulle skep is hulle dinamiese kanon waarvoor hulle gesag opeis en aan die hand waarvan hulle religieus funksioneer. Dit bepaal hulle identiteit en legitimeer hulle wyse van bestaan. Dit verskaf aan hulle die verwysingsraamwerk vir hulle kerklike praktyk en lewensetiek.

Die belangrike is egter dat hierdie kanon nie in die Bybel lê nie, maar in die gebruik van die Bybel. Brett se poging om aan Childs se kanonbegrip legitimiteit te gee 
vanuit Gadamer se konsep van die 'klassieke teks,' oortuig daarom nie werklik nie. Hiervolgens kan die Bybel, beskou word '... as the product of the best theological 'science', or critical reflection, to come out of the biblical period ...' (Brett 1991:133). Die mens wat met 'n effektiewe historiese bewussyn leef, ontmoet in die kiassieke teks die waarheid wat bowe-tydelik en bowe-indiwidueel is en superieure insigte bied waardeur sy voor- en afkeure bepaal word. In Childs se idioom praat die kanonteks vir hnmself met elke nuwe geslag en bied 'n waarheidswaarde wat gedemonstreer word in die godsdiensgemeenskappe vir wie die Bybel kanoniek is. Volgens Brett kan Childs se kanonbenadering bevorder word deur aan te sluit by die intra-tekstuele teologie van Frei, Lindbeck en Thiemann. Volgens hulle is die referente na die werklikheid gegee in die taal en vorm van die Bybelse tradisies. 'The biblical text is seen as a kind of framework, a symbolic universe given by the tradition, through which the Christian interprets the world' (Brett 1991:156).

Die 'framework' bly egter net 'n geraamte sonder vleis as dit nie vanuit die werklikheid in al sy dimensies gevul word nie. Om enigsins aanspraak te maak op geldigheid sal die teologiese metafoor wat in die diskoers ontwikkel word, die kant en wal van die hier en die nou moet raak.

\section{SLOTSOM}

* Dit is nie moontlik om Artikel 4 van die NGB ongeartikuleerd na te sé nie. Buiten dat die boek Klaagliedere in die lys ontbreek, moet erken word dat hierdie een lys van boeke naas ander is, gekies deur 'n bepaalde geloofsgemeenskap onder bepaalde omstandighede vir bepaalde redes.

* Die gesag van hierdie kanonieke boeke lê nie volgens die latere ortodoksistiese siening in die tekstualiteit daarvan nie, maar in die funksionaliteit daarvan om 'n proses te fasiliteer waarin mense in hulle oneindige pluriformiteit op hoeveel wyses met die almagtige God gekonfronteer word en deur. God se almag bemagtig word om vanuit hulle konkrete situasie voor en met God te lewe.

* Kanonisiteit beteken meer as net 'n vasgestelde aantal woorde in 'n vasgestelde teks. Dit gaan ook nie cor cen of ander inherente mag van woorde nie. Dit gaan oor 'n geloofstradisie wat in 'n verskeidenheid van tekste met 'n variasie van bewoording neerslag gevind het. Daar is nie net cen vorm van die kanonteks nie en daar kan ook nie net cen amptelike vertaling van die Skrif wees nie. 
* Soos in die verstaan van die gesag van die Skrif, is die volledige sosio-kulturele konteks van mense en gemeenskappe ingesluit in die totstandkoming en die funksionering van die kanon. Dit is 'n multi-dimensionele aangeleentheid wat op interdissiplinêre en omvattende vlak hanteer moet word.

* Childs se kanonbenadering is ter sake in soverre Rendtorff dit vertolk het as 'n holistiese benadering tot die Skrif. Die holisme sal egter verder moet gaan as bloot net die literêre komposisie van die kanon. Die totale situasie van historiese geloofsgemeenskappe wat in 'n konkrete wêreld leef en 'n geloofstradisie voortsit en aan die nageslag deurgee, moet ter sprake kom.

* Sanders se verstaan van kanon as 'n dinamiese proses is baie belangrik. Hoewel dit moeilik is om hierdie proses anders as in terme van mense en hulle ervarings te beskryf (wie is ons en wat moet ons doen?), kan in die lig van die teologisering wat hy in die proses raaksien, die klem meer verskuif word na die vlak van interaksie tussen God en mens. Die funksie van die kanon lê baie meer op die aksie van God wat in hierdie kanon en sy tradisie mense só ontmoet dat elke outonome menslike mag en aanspraak op gesag gedekanoniseer word sodat dit God se almag as die enigste gesag bely.

\section{Literatuurverwysings}

Bird, P A 1994. The authority of the Bible, in The New Interpreter's Bible, Volume 1, 33-64.

Brakke, D 1994. Canon formation and social conflict in fourth-century Egypt: Athanasius of Alexandria's thirty-ninth Festal Letter. HTR 87/4, 395-419.

Bossman, D M 1993. Canon and culture: Biblical theology in context. Ongepubliseerde voordrag vir die byeenkoms van die 'Context group', Portland, Oregon, 1821 Maart 1993.

Brett, M G 1991. Biblical criticism in crisis? The impact of the canonical approach on Old Testament studies. Cambridge: Cambridge University.

Breytenbach, A P B 1997. Meesternarratiewe, kontra-narratiewe en kanonisering: 'n Perspektief op sommige profetiese geskrifte. HTS 53/4, 1161-1186.

Claassen, G F 1996. Die kanoniese benadering van B S Childs. DD-proefskrif, Universiteit van Pretoria.

Collins, J J 1995. Before the canon: Scriptures in second temple Judaism, in Mays, J L, Petersen, D L \& Richards, K H (eds) 1995. OT Interpretation: Past, present, and future; Essays in honor of Gene M Tucker. Nashville: Abingdon. 
Deist, F E 1988. Wimesses to the Old Testament: Introducing Old Testament textual criticism. Pretoria: NG Kerkboekhandel.

1992. 'Canonical criticism', reformed theology and developments in the textual criticism of the First Testament. Journal of Northwest Semitic Languages. 18, 37-47.

1995. Canonical literature: Some ideology-critical observations. Acta Academica Supplementum 1, 66-80.

Diensboek van die Nederduitsch Hervormde Kerk van Afrika 1987. Pretoria: Kital.

Dunbar, D G 1995. The biblical canon, in Carson, D A \& Woodbridge, J D (eds) 1995. Hermeneutics, authority, and canon, 295-360. Grand Rapids: Baker Books.

Gottwald, N K 1985. Social matrix and canonical shape. Theology Today 42/3, 307321.

Jeismann, K-E 1985. Geschichte als Horizont der Gegenwart: Über der Zusammenhang von Vergangenheits Deutung, Gegenwartsverständnis und Zukunftperspektive. Paderborn: Schöningh.

Kruger, H A J 1994. The canon critical approach as a means of understanding the Old Testament. OTE 7/4, 181-197.

Leiman, S Z 1981. Inspiration and canonicity: Reflections on the formation of the Biblical canon, in Sanders, E P 1981. Jewish and Christian self-definition, 6-63. Volume 2 (Aspects of Judaism in the Graeco-Roman period.? London: SCM.

Ohlhoff, H 1993. Kanon en kanonvorming. Tydskrif vir Letterkinde, 31/4, 58-66.

Rendtorff, R 1994. 'Canonical Interpretation'. A new approach to Biblical texts. Studia Theologica 48, 3-14.

Sanders, J A 1995. Scripture as canon for post-modern times. BTB 25/2, 56-63.

Scalise, C J 1994. Canonical hermeneutics: Childs and Barth. SJTh 47, 61-88.

Seitz, C R 1994. We are not prophets or apostles: The impact of Brevard Childs. Dia$\log 33 / 2,89-93$

Van Aarde, A G 1994. The epistemic status of the New Testament and the emancipatory living of the historical Jesus in engaged hermeneutics. Neotestamentica 28 (2), 575-596.

Veltri, G 1990. Zur traditionsgeschichtlichen Entwicklung des Bewußtseins von einem Kanon: Die Yavneh-frage. Journal for the Study of Judaism 21/2, 210-226.

Tov, E 1992. Textual criticism of the Bible. Assen/Maastricht: Van Gorcum.

Van der Kooij, A 1995. De canonvorming van de Hebreeuwse bijbel, het Oude Testament: Een overzicht van recente literatuur. NThT 49/1, 42-65.

Venter, P M 1997. 'n Verkenning van postmodernisme en 'n ekskurs op Daniël 7-12. HTS 53/3, 580-598. 